\title{
Pengaruh Konflik terhadap Kinerja Karyawan Bagian Produksi pada PT. YKT Gear Indonesia
}

\author{
Agung Surya Dwianto ${ }^{1}$, Pupung Purnamasari ${ }^{2}$, Yodi Pirmansyah ${ }^{3}$ \\ STIE Pertiwi \\ Jalan Ir. H. Juanda Bekasi \\ dwiantoagungsurya@gmail.com ${ }^{1}$ \\ pupungpurnamasari@gmail.com ${ }^{2}$ \\ yodipirmansyah@gmail.com ${ }^{3}$
}

\begin{abstract}
Abstrak- Konflik adalah ketidaksesuaian antara dua atau lebih anggota-anggota atau kelompok (dalam suatu organisasi atau perusahaan) yang harus membagi sumber daya yang terbatas atau kegiatan-kegiatan kerja dan atau karena kenyataan bahwa mereka mempunyai perbedaan status, tujuan, nilai, atau persepsi. Konflik dapat terjadi dimanapun termasuk dalam sebuah perusahaan, konflik terjadi karena masing-masing pihak atau salah satu pihak merasa dirugikan. Konflik dapat berakibat negatif tetapi dapat pula berakibat positif. Penelitian ini dilakukan di sebuah perusahaan yaitu di PT YKT Gear Indonesia, tujuan dari penelitian ini adalah untuk mengetahui sejauhmana konflik dapat berpengaruh terhadap karyawan PT YKT Gear Indonesia, apakah pengaruh konflik dapat menurunkan kinerja karyawan PT YKT Gear Indonesia atau dapat menaikkan kinerja karyawan PT YKT Gear Indonesia. Dari hasil penelitian ini dapat di simpulkan bahwa berdasarkan hasil analisis regresi sederhana, konflik memiliki pengaruh positif terhadap kinerja karyawan yaitu sebesar 0,344. Artinya kenaikan satu poin pada Konflik, maka akan mengakibatkan naiknya Kinerja Karyawan pada PT YKT Gear Indonesia sebesar 0,344 dan sebaliknya, jika terjadi penurunan satu poin pada Konflik, maka akan diikuti pula oleh penurunan Kinerja Karyawan sebesar 0,344 pada PT YKT Gear Indonesia. Sedangkan berdasarkan hasil analisis korelasi sederhana pengaruh konflik terhadap kinerja adalah positif sedang karena nilai $r$ yang dihasilkan sebesar 0,434 . Berdasarkan koefisien determinasi dapat disimpulkan bahwa konflik memiliki kontribusi sebesar $\mathbf{1 8 , 8 1 \%}$ terhadap kinerja karyawan PT YKT Gear Indonesia, sisanya sebesar $\mathbf{8 1 , 9 1 \%}$ dipengaruhi oleh factor lain.
\end{abstract}

Kata Kunci- Konflik, Kinerja Karyawan.

\section{PENDAHULUAN}

Suatu organisasi atau Instansi didirikan dengan berbagai macam tujuan yang telah ditetapkan. Tujuan Instansi dapat tercapai apabila manajemen dapat mengelola, menggerakan dan menggunakan sumber daya yang dimiliki termasuk sumber daya manusianya, secara efektif dan efisien. Walaupun didukung dengan sarana dan prasarana serta sumber daya yang berlebihan, tetapi tanpa dukungan sumber daya manusia yang handal, kegiatan perusahaan tidak akan terselesaikan dengan baik.

Menurut Mathis dan Jackson (2009:76) :

Manajemen sumber daya manusian dapat didefinisikan sebagai suatu proses perencanaan, pengorganisasian, penyusunan staf, penggerakan, dan pengawasan, terhadap pengadaan, pengembangan, pemberian kompensasi, pengintegrasian, pemeliharaan, dan pemisahan tenaga kerja untuk mencapai tujuan organisasi.

Hal ini menunjukkan bahwa sumber daya manusia salah satu kunci pokok yang harus diperhatikan dengan segala kebutuhannya. Sebagai kunci pokok, sumber daya manusia akan menentukan keberhasilan pelaksanaan kegiatan perusahaan.

Instansi atau perusahaan merupakan organisasi yang terdiri dari sekumpulan orang yang bekerja sama untuk mencapai tujuan yang telah ditentukan. Orang-orang yang ada dalam organisasi, baik sebagai pegawai atau pegawai, memegang peranan menentukan, karena berkembang tidaknya suatu organisasi tergantung pada sumber daya manusia, sebagai penentu dan penggerak jalannya organisasi. Ketika orang-orang dalam suatu organisasi berkolaborasi dalam kerja, maka bisa saja muncul konflik atau perselisihan.

$$
\text { Hasibuan (2008:199) menjabarkan }
$$

Konflik sebagai berikut :

"Konflik adalah persaingan yang kurang sehat berdasarkan ambisi dan sikap emosional dalam memperoleh kemenangan".

Pandangan lama menganggap konflik dalam organisasi sebagai suatu hal yang negatif, menjurus pada perpecahan instansi, karena itu harus dihilangkan 
sebab menghambat kinerja optimal. Perselisihan dianggap sebagai indikasi adanya sesuatu yang salah pada organisasi, dan itu berarti aturan-aturan organisasi tidak dijalankan. Pada saat ini, sejumlah ahli manajemen beranggapan bahwa konflik di dalam organisasi tidak dapat dihindari, dan keberadaannya dapat memperjelas masalah, mengetahui kekurangan organisasi, solusi terhadap kelemahan, dapat mengarahkan pada tujuan organisasi.

Pengaruh antara Konflik terhadap

Kinerja Karyawan tercermin dalam pernyataan Mangkuprawira (2009:201) yaitu :

Konflik harus dicegah dan diselesaikan sedini mungkin, supaya tetap terwujud kerjasama yang baik, terhindar dari ketegangan dan perpecahan di antara sesama karyawan. Persaingan sehat harus selalu diciptakan dan dibina agar dinamika organisasi, kreativitas, intropeksi diri, pengembangan diri, moral kerja, dan produktivitas kerja karyawan meningkat sehingga tujuan perusahaan, karyawan, dan masyrakat tercapai.

Konflik dalam sebuah organisasi akan berdampak pada performa organisasi. Jika terjadi konflik, pada level yang rendah, maka prestasi kerja dari suatu unit kerja akan rendah. Sebaliknya, jika terjadi konflik konstruktif, maka kinerja unit kerja mulai meningkat. Jika konflik terus terjadi, maka ia akan berubah menjadi disfungsional dan seterusnya menjadi konflik yang destruktif. Tenaga, energi, waktu dan kekuasaan, akan terserap oleh konflik yang terjadi. Kinerja unit kerja akan semakin menurun. Organisasi menjadi sakit dan tidak produktif lagi.

Rivai dan Sagala (2011:548)

berpendapat Kinerja Karyawan sebagai berikut :

"Kinerja merupakan perilaku nyata yang ditampilkan setiap orang sebagai prestasi kerja yang dihasilkan oleh karyawan sesuai dengan perannya dalam perusahaan".

Penelitian dilakukan di PT. YKT Gear. PT. YKT Gear Indonesia adalah perusahaan yang bergerak dibidang Manufaktur Yang memproduksi Gear Dan Camshaft PT. YKT Gear Indonesia beralamat di Kawasan Industri Mitra Karawang Jl. Mitra Raya III Blok 1-2 No. 7, Desa Parungmulya Kec. Ciampel Kab. Karawang Jawa Barat. PT. YKT Gear Indonesia tentunya sangat concern terhadap manajamen sumber daya manusia utamanya menyangkut Konflik dan Kinerja Karyawan.

Namun terdapat fenomena masalah yang terjadi mengenai Konflik yaitu karyawan di PT. YKT Gear Indonesia kurang bertanggung jawab dalam menyelesaikan pekerjaanya dalam menjalankan standar prosedur untuk memenuhi kualitas dan kuantitas yang diharapkan. sehingga menimbulkan konflik antara atasan dengan bawahan. Selain itu adanya ketidaksepahaman antara sesama karyawan dimana beberapa karyawan seringkali kurang harmonis dan sering terjadi perselisihan.

Akibat adanya masalah Konflik yang kurang tepat maka terjadilah masalah dimana karyawan menjadi kurang maksimal dalam bekerja dan adanya Gap (selisih) antara Sistem dan Aktual Barang karena adanya konflik antar karyawan dan konflik dengan atasan. Konflik yang terjadi di perusahaan ini dapat membuat performa perusahaan tentunya menurun dan kinerja setiap individu karyawan di perusahaan tersebut kurang maksimal.

\section{KAJIAN PUSTAKA}

Suatu konflik dapat terjadi karena masingmasing pihak atau salah satu pihak merasa dirugikan. Kerugian ini bukan hanya bersifat material tetapi dapat juga bersifat non material. Untuk mencegah konflik, maka pertama-tama kita harus mempelajari sebabsebab yang dapat menimbulkan konflik tersebut.

Hal-hal yang menyebabkan konflik menurut Pace (2013:19) antara lain adanya tujuan yang ingin dicapai, ego manusia, kebutuhan, perbedaan peendapat, salah paham, perasaan dirugikan dan perasaan sensitif.

Pada bagian awal telah dibahas sedikit bahwa konflik tidak mesti menyebabkan akibat negatif. Dengan kata lain akibat yang ditimbulkan oleh konflik pada dasarnya ada dua hal pokok yaitu: negatif atau merugikan dan positif atau menguntungkan.

Akibat negatif atau merugikan dari adanya konflik dalam suatu organisasi sebagaimana disampaikan oleh Mangkunegara (2008:200) yaitu:

1. Kerjasama kurang serasi dan harmonis di antara para karyawan.

2. Memotivasi sikap-sikap emosional karyawan.

3. Menimbulkan sikap apriori karyawan.

4. Meningkatkan absen dan turnover karyawan.

5. Kerusakan produksi dan kecelakaan semakin meningkat. 
Adapun akibat-akibat positif /menguntungkan dari adanya konflik adalah sebagai berikut:

1. Menimbulkan kemampuan mengoreksi diri sendiri

2. Meningkatkan prestasi

3. Pendekatan yang lebih baik

4. Mengembangkan alternatif yang lebih baik Jenis-Jenis Konflik

Konflik merupakan suasana batin yang berisi kegeliasahan dan pertentangan antara dua motif atau lebih mendorong seseorang untuk melakukan dua atau lebih kegiatan yang saling bertentangan. Bila tidak dikendalikan secara baik akan menimbulkan dampak negatif yang pada akhirnya dapat menimbulkan perpecahan diantara individu yang ada dalam perusahaan.

Terdapat lima jenis konflik dalam kehidupan organisasi sebagaimana disampaikan oleh Rivai (2011:49):

1. Konflik dalam diri individu

2. Konflik antar individu dalam organisasi yang sama

3. Konflik antar individu dan kelompok

4. Konflik antar kelompok dalam organisasi yang sama

5. Konflik antar organisasi

Cara Mengelola Konflik

Rivai (2011:106) mengemukakan terdapat 3 cara mengelola konflik, yaitu:

1. Metode stimulasi konflik

Metode ini digunakan untuk menimbulkan rangsangan anggota, karena anggota pasif yang disebabkan oleh situasi di mana konflik terlalu rendah. Metode ini digunakan untuk merangsang konflik yang produktif. Dan metode stimulasi konflik ini meliputi:

a. Pemasukan atau penempatan orang luar kedalam kelompok

b. Penyusunan kembali organisasi

c. Penawaran bonus, pembayaran insentif, dan penghargaan untuk mendorong persaingan

d. Pemilihan manjer-manajer yang tepat

e. Perlakuan yang berbeda dengan kebiasaan.

2. Metode pengurangan konflik

Metode ini mengurangi antagonism (permusuhan) yang ditimbulkan oleh konflik. Metode ini mengelola tingkat konflik melalui "pendinginan suasana" tetapi tidak mengenai masalah-masalah yang semula menimbulkan konflik.
Metode ini ada dua. Pertama, mengganti tujuan yang menimbulkan persaingan dengan tujuan yang lebih bisa diterima kedua kelompok. Metode kedua, mempersatukan kedua kelompok yang bertentangan untuk menghadapi "ancaman" atau "musuh" yang sama.

3. Metode penyelesaian konflikAda tiga metode penyelesaian konflik yang sering digunakan, yaitu dominasi atau penekanan, kompromi, dan pemecahan masalah integratif.

a. Dominasi atau penekanan.

Dominasi dan penekanan dapat dilakukan dengan beberapa cara, yaitu :

1) Kekerasan (forcing) yang bersifat penekanan otokratik

2) Penenangan (smoothing) merupakan cara yang lebih diplomatis

3) Penghindaran (avoidance) di mana manajer menghindar untuk mengambil posisi yang tegas

4) Aturan mayoritas (majority rule) mencoba untuk menyelesaikan konflik antar kelompok dengan melakukan pemungutan suara (voting) melalui prosedur yang adil.

b. Kompromi.

Manajer mencoba menyelesaikan konflik melalui jalan tengah yang dapat diterima oleh pihak yang bertikai. Bentuk-bentuk kompromi meliputi:

1) Pemisahan (separation), dimana pihak-pihak yang sedang bertikai dipisahkan sampai mereka mencapai persetujuan.

2) Perwasitan (arbitrasi), dimana pihak ketiga (biasanya manajer) diminta memberikan pendapat

3) Kembali ke peraturan-peraturan yang berlaku, di mana kemacetan dikembalikan pada ketentuan-ketentuan tertulis yang berlaku dan menyetujui bahwa peraturan-peraturan yang memutuskan penyelesaian konflik

4) Penyuapan (bribing). Salah satu pihak menerima kompensasi dalam pertukaran untuk tercapainya penyelesaian konflik.

c. Pemecahan masalah integratif (secara menyeluruh).

Konflik antar kelompok diubah menjadi situasi pemecahan masalah bersama melaui teknik-teknik pemecahan masalah. Di samping penekanan konflik atau pencarian kompromi, kedua belah pihak secara terbuka mencoba menemukan penyelesaian yang dapat diterima semua pihak. 
Berikut ada tiga macam metode penyelesaian integratif, yaitu:

1) Konsensus. Kedua belah pihak bertemu bersamasama untuk mencari penyelesaian terbaik masalah mereka dan bukan mencari kemenangan satu pihak.

2) Konfrontasi. Kedua belah pihak menyatakan pendapatnya secara langsung satu sama lain, dan dengan kepemimpinan yang terampil serta kesediaan untuk menerima penyelesaian, suatu penyelesaian konflik yang rasional sering dapat ditemukan.

3) Penggunaan tujuan-tujuan yang lebih tinggi. Dapat juga menjadi metode menyelesaikan konflik bila tujuan tersebut disetujui bersama.

Kinerja Karyawan

Konflik dalam sebuah organisasi akan berdampak pada performa organisasi. Jika terjadi konflik, pada level yang rendah, maka prestasi kerja dari suatu unit kerja akan rendah. Sebaliknya, jika terjadi konflik konstruktif, maka kinerja unit kerja mulai meningkat. Jika konflik terus terjadi, maka ia akan berubah menjadi disfungsional dan seterusnya menjadi konflik yang destruktif. Tenaga, energi, waktu dan kekuasaan, akan terserap oleh konflik yang terjadi. Kinerja unit kerja akan semakin menurun. Organisasi menjadi sakit dan tidak produktif.

Kinerja karyawan sangatlah penting untuk diperhatikan demi pencapaian tujuan sebuah perusahaan dan untuk pencapaian tujuan tersebut secara optimal perusahaan dapat meningkatkan kinerja karyawannya. Salah satu cara untuk meningkatkan kinerja karyawan adalah dengan melakukan penilaian kinerja karyawan.

Di bawah ini merupakan definisi kinerja karyawan yang disampaikan oleh beberapa ahli:

$$
\text { Rivai dan Sagala (2011:548) }
$$

berpendapat bahwa:

"Kinerja adalah perilaku nyata yang ditampilkan setiap orang sebagai prestasi kerja yang dihasilkan oleh karyawan sesuai dengan perannya dalam perusahaan dengan tanggung jawab yang diberikan kepadanya".

Sedangkan Mangkunegara

(2013:67)

mendefinisikan kinerja karyawan sebagai berikut:

"Kinerja (prestasi kerja) adalah hasil kerja secara kualitas dan kuantitas yang dicapai oleh seseorang pegawai dalam melaksanakan tugasnya sesuai dengan tanggung jawab yang diberikan kepadanya".
Sedangkan menurut Mangkuprawira (2009:220) menjelaskan bahwa:

"Performance atau Kinerja adalah hasil kerja yang dapat dicapai oleh seseorang atau kelompok orang dalam suatu organisasi sesuai dengan wewenang dan tanggungjawabnya masing-masing dalam upaya pencapaian tujuan organisasi".

Berdasarkan beberapa pendapat beberapa ahli di atas maka dapat disimpulkan bahwa kinerja karyawan adalah perilaku nyata yang ditampilkan setiap orang sebagai prestasi kerja yang dihasilkan oleh karyawan sesuai dengan perannya dalam perusahaan dengan didasari pada kemampuan teknis, kemampuan konseptual, dan kemampuan hubungan interpersonal yang dimilikinya dalam membantu tercapainya tujuan perusahaan.

Salah satu unsur manajemen adalah pengembangan. Hal ini akan maksimal jika ada informasi awal dari kinerja karyawan yang akan dikembangkan. Penilaian pretasi kerja sangat penting untuk dilakukan oleh seorang atasan, karena hasil penilaian tersebut akan digunakan untuk memperbaiki keputusan-keputusan yang akan atau telah diambil oleh personalia dan memberikan umpan balik kepada karyawan tentang kinerjanya.

Menurut Hasibuan (2008:135) terdapat manfaat yang dapat dipetik dari penilaian prestasi kerja, yaitu sebagai berikut:

1. Perbaikan prestasi kerja

2. Penyesuaian kompensasi

3. Keputusan penempatan

4. Kebutuhan latihan dan pengembangan

5. Perencanaan dan pengembangan karier

6. Penyimpangan-penyimpangan proses staffing

7. Ketidakakuratan informasioanal

8. Kesalahan desain pekerjaan

9. Kesempatan kerja yang adil

10. Tantangan eksternal

Pengaruh Konflik terhadap Kinerja Karyawan

Pandangan lama menganggap konflik dalam organisasi sebagai suatu hal yang negatif, menjurus pada perpecahan instansi, karena itu harus dihilangkan sebab menghambat kinerja optimal. Perselisihan dianggap sebagai indikasi adanya sesuatu yang salah pada organisasi, dan itu berarti aturan-aturan organisasi tidak dijalankan. Pada saat ini, sejumlah ahli manajemen beranggapan bahwa konflik di dalam organisasi tidak dapat dihindari, dan keberadaannya dapat memperjelas masalah, mengetahui kekurangan 
organisasi, solusi terhadap kelemahan, dapat mengarahkan pada tujuan organisasi.

Pengaruh antara Konflik terhadap

Kinerja Karyawan tercermin dalam pernyataan Hasibuan (2013:201) yaitu:

Konflik harus dicegah dan diselesaikan sedini mungkin, supaya tetap terwujud kerjasama yang baik, terhindar dari ketegangan dan perpecahan di antara sesama karyawan. Persaingan sehat harus selalu diciptakan dan dibina agar dinamika organisasi, kreativitas, intropeksi diri, pengembangan diri, moral kerja, dan produktivitas kerja karyawan meningkat sehingga tujuan perusahaan, karyawan, dan masyrakat tercapai.

Berdasarkan pendapat di atas maka dapat ditarik kesimpulan bahwa terdapat pengaruh antara Konflik terhadap Kinerja Karyawan. Oleh sebab itu, maka hal inilah yang mendasari penulis untuk membuat kerangka pemikiran dalam penelitian ini.

\section{Metodologi Penelitian}

Desain penelitian merupakan sebuah rancangan bagaimana suatu penelitian akan dilakukan. Rancangan tersebut digunakan untuk mendapatkan jawaban terhadap pertanyaan penelitian yang dirumuskan. Penelitian ini termasuk ke dalam dua jenis penelitian yaitu: Penelitian Deskriptif dan Asosiatif

Menurut Sugiyono (2011:13), "Penelitian deskriptif yaitu penelitian yang dilakukan untuk mengetahui nilai variabel mandiri, baik satu variabel atau lebih (independen) tanpa membuat perbandingan, atau menghubungkan dengan variabel yang lain".

Sedangkan Penelitian asosiatif merupakan penelitian yang bertujuan untuk mengetahui pengaruh ataupun juga hubungan antara dua variabel atau lebih". Uji Asumsi Klasik

Sebelum melakukan uji hipotesis, terlebih dahulu harus dilakukan uji asumsi klasik. Tujuan pengujian asumsi klasik ini untuk memberikan kepastian bahwa persamaan regresi yang didapatkan memiliki ketepatan dalam estimasi, tidak bias dan konsisten, apakah data bersifat autokorelasi, multikolinearitas, atau heteroskedastisitas.

Didalam penelitian ini, penulis hanya menggunakan uji normalitas dan uji heteroskedastisitas karena uji autokorelasi hanya digunakan pada penelitian times series, dan uji multikolinearitas hanya digunakan pada penelitian dengan variabel independen lebih banyak. Berikut penjelasanya: a. Uji Heterokedastisitas

Dalam persamaan regresi berganda perlu diuji mengenai sama atau tidak varians dari residual dari observasi yang satu dengan observasi lainnya. Jika residual mempunyai varians yang sama, disebut homoskedastisitas. Dan jika variansya tidak sama disebut Heteroskedastisitas.

b. Uji Normalitas Data

Uji Normalitas bertujuan untuk mengetahui apakah dalam model regresi, variable terikat dan variable bebas memiliki distribusi normal atau mendekati normal. Pembuktian apakah data tersebut memiliki distribusi normal atau tidak dapat dilihat pada bentuk distribusi datanya (Riduwan, 2011:160) cara yang dapat digunakan dalam Uji Normalitas yaitu: Analisis Grafik dan Kurva Probability Plot (P-Plot).

Metode Analisis Kuantitatif

Pada penelitian ini menggunakan teknis analisis data secara kuantitatif yakni teknik analisis berupa angka-angka yang dilakukan peritungan untuk menganalisa kondisi dan perilaku data sehingga melalu hasil perhitungan tersebut akan diketahui pengaruh, gambaran, dan penarikan kesimpulan dari data tersebut (Supranto, 2009: 144).

Adapun data-data tersebut diperoleh dari hasil jawaban kuesioner yang kemudian akan diuji dengan Analisis Regresi Sederhana, analisis Korelasi Sederhana (Product Moment) yang kemudian dilanjutkan dengan Analisis Koefesien Determinasi serta Uji Keberartian Koefesien Korelasi (Uji t). Berikut ini adalah penjabaran mengenai langkahlangkah dalam analisis kuantitatif yang peneliti lakukan dalam penelitian ini adalah:

a. Analisis Regresi Sederhana

Menurut Sujarweni (2015:111) menyatakan bahwa, "Regresi bertujuan untuk menguji pengaruh antar variabel yang satu dengan variabel lain".

Sehingga melalui metode ini penulis memperoleh persamaan yang dapat digunakan memprediksi Kinerja Karyawan melalui variabel Konflik di PT. YKT Gear Indonesia.

Persamaan yang diperoleh dengan metode ini adalah $\mathrm{Y}=\mathrm{a}+\mathrm{bX}$, dimana nilai $\mathrm{a}$ dan $\mathrm{b}$ diperoleh dengan menggunakan rumus:

$$
\begin{aligned}
& \mathrm{b}=\frac{\mathrm{n} \cdot \sum \mathrm{XY}-\sum \mathrm{X} \sum \mathrm{Y}}{\mathrm{n} \cdot \sum \mathrm{X}^{2}-\left(\sum \mathrm{X}\right)^{2}} \\
& \mathrm{a}=\frac{\sum \mathrm{Y} \sum \mathrm{X}^{2}-\sum \mathrm{X} \sum \mathrm{XY}}{\mathrm{n} \cdot \sum \mathrm{X}^{2}-\left(\sum \mathrm{X}\right)^{2}}
\end{aligned}
$$


Keterangan :

$$
\begin{aligned}
& \mathrm{n}=\text { jumlah sampel } \\
& \mathrm{a}=\text { konstanta } \\
& \mathrm{b}=\text { koefesien } \\
& \mathrm{Y}=\text { Dependent Variable (variabel terikat) } \\
& \mathrm{X}=\text { Independent Variable (variabel bebas) }
\end{aligned}
$$

b. Analisis Koefesien Korelasi

Rumus yang digunakan dalam Analisis koefesien korelasi ini adalah sebagai berikut:

$$
\begin{aligned}
& r=\frac{n \cdot \sum x y-\sum x \sum y}{\sqrt{\left[\left(n \cdot \sum x^{2}\right)-\left(\sum x\right)^{2}\right] \cdot\left[\left(n \cdot \sum y^{2}\right)-\left(\sum y\right)^{2}\right]}} \\
& \text { Keterangan: } \\
& \mathrm{n} \quad=\text { jumlah sampel } \\
& \mathrm{r} \quad=\text { nilai koefesien korelasi }
\end{aligned}
$$

Menurut Sugiyono (2011:212), “Analisis koefisen korelasi pearson digunakan untuk mengukur kuat atau lemahnya dan hubungan linier yang searah atau berlawanan antara variabel bebas $(\mathrm{X})$ dan variabel terikat (Y)".

Hubungan linier yang searah dapat dilihat dari hasil perhitungan nilai $r$ yang positif dan hubungan linier yang berlawanan dapat dilihat dari hasil perhitungan nilai $r$ yang negative, maka dengan metode ini peneliti mempunyai tujuan untuk meyakinkan bahwa pada kenyataannya terdapat hubungan antara Konflik dan Kinerja Karyawan di PT. YKT Gear Indonesia.

\section{c. Analisis Koefesien Determinasi}

Koefesien determinasi dilambangkan dengan $r^{2}$. Nilai ini menyatakan proporsi variasi keseluruhan dalam nilai variabel dependent yang dapat diterangkan

\section{Scatterplot}

\section{Dependent Variable: kinerja_karyawan}

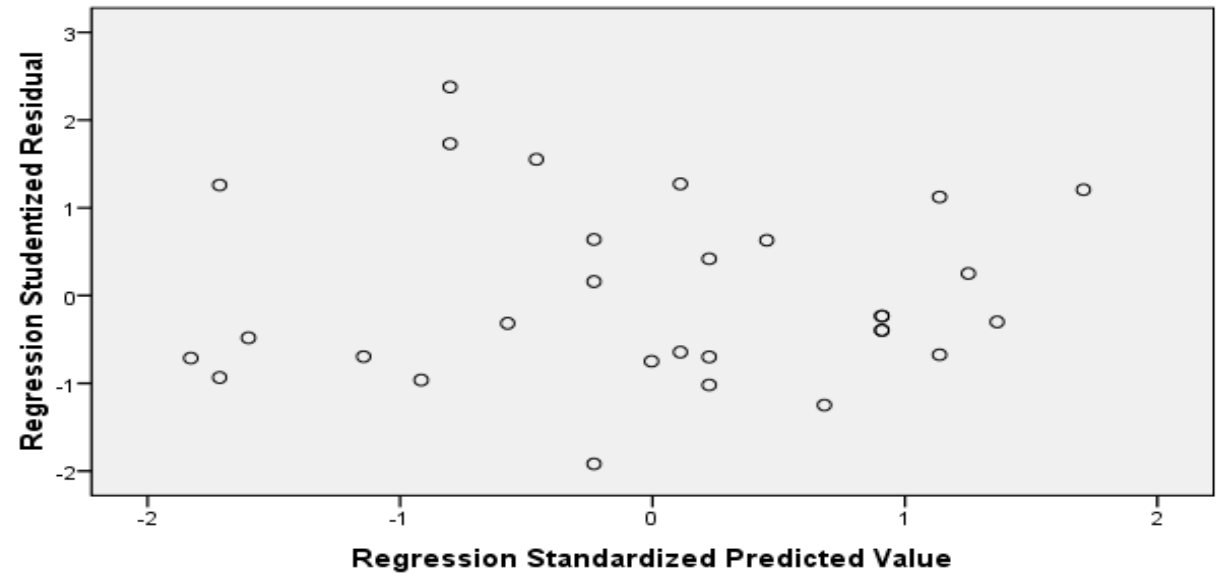

atau diakibatkan oleh hubungan linear dengan variabel independent, selain itu sisanya diterangkan oleh variabel lain.

$\mathrm{Kd}=(r)^{2} \times 100 \%$

Keterangan:

$\mathrm{KD}=$ nilai koefesien determinasi

$\mathrm{r}=$ nilai koefesien korelasi

Dengan analisis koefesien determinasi ini peneliti dapat mengetahui besarnya persentase kontribusi pengaruh Konflik terhadap Kinerja Karyawan di PT. YKT Gear Indonesia.

\section{Pembahasan}

Uji ini bertujuan untuk menguji apakah dalam sebuah model regresi terjadi ketidaksamaan varians dari residual, dari satu pengamatan ke pengamatan yang lain. Jika varians dari residual dari satu pengamatan ke pengamatan yang lain tetap, maka disebut homoskedastisitas dan jika varians berbeda, disebut heterokedastisitas. Model regresi yang baik adalah tidak terjadi heterokedastisitas. Untuk mendeteksi ada tidaknya heterokedastisitas dapat digunakan metode grafik Scatterplot yang dihasilkan dari output program SPSS versi 24, apabila pada gambar menunjukkan bahwa titik-titik menyebar secara acak serta tersebar baik diatas maupun di bawah angka 0 pada sumbu Y, maka hal ini dapat disimpulkan tidak terjadi adanya heterokedastisitas pada model regresi (Husein Umar,2012). 
Gambar 4.2

Hasil Pengujian Heterokedastisitas

Dari grafik tersebut terlihat titik-titik yang menyebar secara acak, tidak membentuk suatu pola tertentu yang jelas, serta tersebar baik diatas maupun di bawah angka 0 (nol) pada sumbu Y, hal ini berarti tidak terjadi penyimpangan asumsi klasik heterokedastisitas pada model regresi yang dibuat, dengan kata lain menerima hipotesis homoskedastisitas.

Uji normalitas data

Uji normalitas bertujuan untuk menguji apakah dalam model regresi, variable bebas dan variable terikat, keduanya terdistribusikan secara normal ataukah tidak. Hipotesis Objek (Ho) merupakan populasi berdistribusi normal dan
Hipotesis Alternatif (Ha) merupakan populasi tidak berdistribusi normal. Teknik pengujian normalitas data dengan metode SPSS 23 dengan criteria pengujian: Tolak Ho jika P Value (Sig) > taraf signifikan 0,05

Normalitas data dalam penelitian dilihat dengan cara memperhatikan titik-titik pada Normal $P$ Plot Regression Standardized Residual dari variable terikat. Persyaratan dari uji normalitas adalah jika data menyebar disekitar garis diagonal dan mengikuti arah garis diagonal, maka model regresi memenuhi asumsi normalitas. Jika data menyebar jauh dari garis diagonal dan atau tidak mengikuti garis diagonal, maka model regresi tidak memenuhi asumsi normalitas.

Dependent Variable: kinerja_karyawan

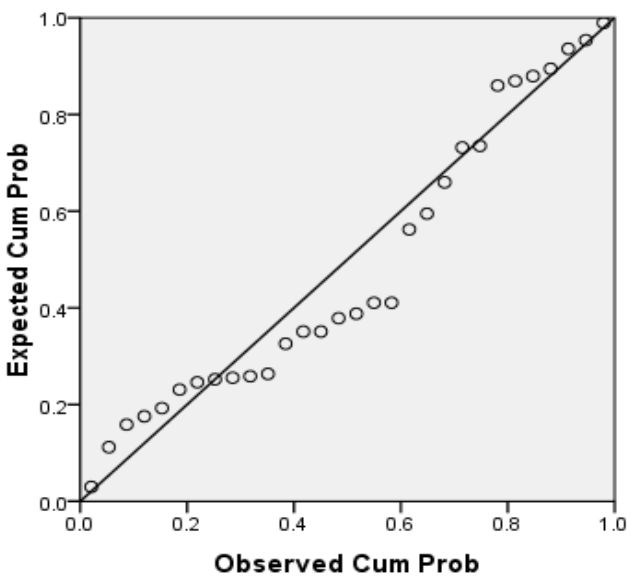

Hasil Pengujian Normalitas

Dari gambar tersebut didapatkan hasil bahwa semua data berdistribusi secara normal, sebaran data berada disekitar garis diagonal.

Analisis Regresi Sederhana

Berdasarkan tabel penolong di atas maka penulis dapat melakukan analisis regresi sederhana sebagai berikut:

*) Mencari nilai b :

$$
\begin{aligned}
& \mathrm{b}=\frac{\mathrm{n} \sum \mathrm{XY}-\sum \mathrm{X} \sum \mathrm{Y}}{\mathrm{n} \sum \mathrm{X}^{2}-\left(\sum \mathrm{X}\right)^{2}} \\
& \mathrm{~b}=\frac{(30 \times 92717)-(1681 \times 1641)}{(30 \times 96421)-(1681)^{2}}
\end{aligned}
$$

$\mathrm{b}=\frac{(2781510)-(2758521)}{(2892630)-(2825761)}$

$\mathrm{b}=\frac{22989}{66869}$

$\mathrm{b}=0,344$

*) Mencari nilai a :

$\mathrm{a}=\underline{\sum \mathrm{Y}-\mathrm{b} \cdot \sum \mathrm{X}}$

$\mathrm{a}=\frac{(1641)-(0,344 \times 1681)}{30}$

$\mathrm{a}=\frac{(1641)-(577,914)}{30}$ 


$$
\begin{aligned}
& a=\frac{1063,086}{30} \\
& a=35,436
\end{aligned}
$$

Berdasarkan perhitungan di atas maka diperoleh persamaan regresi yang dapat digunakan untuk memprediksi variabel Kinerja Karyawan melalui variabel Konflik yaitu $\mathrm{Y}^{\prime}=35,436+0,344 \mathrm{X}$.

Nilai a sebesar 35,436 memiliki makna bahwa, jika tidak terdapat Konflik pada PT. YKT Gear Indonesia, maka akan tetap terdapat Kinerja Karyawan sebesar 35,436 pada PT. YKT Gear Indonesia tersebut.

Nilai b sebesar 0,344 memiliki makna bahwa, Konflik memiliki pengaruh yang positif terhadap Kinerja Karyawan. Artinya kenaikan satu poin pada Konflik, maka akan mengakibatkan naiknya Kinerja Karyawan pada PT. YKT Gear Indonesia sebesar 0,344 Sebaliknya, jika terjadi penurunan satu poin pada Konflik, maka akan diikuti pula oleh penurunan Kinerja Karyawan sebesar 0,344 pada PT. YKT Gear Indonesia.

Analisis Koefesien Determinasi

Berdasarkan nilai $\mathrm{r}$ pada perhitungan analisis korelasi sederhana, maka penulis dapat melakukan analisis koefesien determinasi sebagai berikut:

$$
\begin{aligned}
& \mathrm{Kd}=\mathrm{r}^{2} \cdot 100 \% \\
& \mathrm{Kd}=(0,434)^{2} .100 \% \\
& \mathrm{Kd}=0,1881.100 \% \\
& \mathrm{Kd}=18,81 \% \\
& \text { Sisanya }=81,19 \%
\end{aligned}
$$

Berdasarkan perhitungan di atas maka dapat disimpulkan bahwa Konflik memiliki kontribusi pengaruh sebesar 18,81\% terhadap Kinerja Karyawan PT. YKT Gear Indonesia. Sedangkan sisanya yang sebesar $81,19 \%$ dipengaruhi oleh faktor lainnya.

\section{Simpulan}

Berdasarkan analisis data di atas maka dapat diperoleh bebearapa kesimpulan, antara lain: Konflik yang terdapat pada PT. YKT Gear Indonesia yaitu cukup baik. Hal ini ditunjukkan dengan nilai rata-rata dari total skor sebesar 56,03 yang terletak pada interval kelas 52,6 - 58,8 yaitu cukup baik. Kinerja Karyawan yang terdapat pada PT. YKT Gear Indonesia yaitu cukup baik. Hal ini ditunjukkan dengan nilai rata-rata dari total skor sebesar 54,70 terletak pada interval kelas 52,2 - 57,2 yaitu cukup baik.

Berdasarkan analisis pengaruh Konflik (X) terhadap Kinerja Karyawan (Y). Diperoleh persamaan regresi yang dapat digunakan untuk memprediksi variabel Kinerja Karyawan melalui variabel Konflik yaitu $Y^{\prime}=35,436+0,344 \mathrm{X}$. Nilai a sebesar 35,436 memiliki makna bahwa, jika tidak terdapat Konflik pada PT. YKT Gear Indonesia, maka akan tetap terdapat Kinerja Karyawan sebesar 35,436 pada PT. YKT Gear Indonesia tersebut. Nilai b sebesar 0,344 memiliki makna bahwa, Konflik memiliki pengaruh yang positif terhadap Kinerja Karyawan. Artinya kenaikan satu poin pada Konflik, maka akan mengakibatkan naiknya Kinerja Karyawan pada PT. YKT Gear Indonesia sebesar 0,344 Sebaliknya, jika terjadi penurunan satu poin pada Konflik, maka akan diikuti pula oleh penurunan Kinerja Karyawan sebesar 0,344 pada PT. YKT Gear Indonesia.

Konflik hanya memiliki kontribusi pengaruh sebesar 18,81 \% terhadap Kinerja Karyawan PT. YKT Gear Indonesia. Sedangkan sisanya yang sebesar 81,19 $\%$ dipengaruhi oleh faktor lainnya.

\section{Saran}

Berdasarkan hasil penelititan, maka dapat disimpulkan sebagai berikut:

Manajemen perusahaan perlu terus mensosialisasi kepada para karyawan supaya memahami tujuan mereka yaitu memajukan perusahaan sehingga persaingan yang terjadi sebaiknya persaingan yang sehat dan positif, bukan saling menjatuhkan yang pada akhirnya mengakibatkan konflik. Hal ini perlu dilakukan mengingat ada temuan masalah dimana beberapa karyawan ingin lebih unggul daripada karyawan lainnya namun mengarah pada persaingan negatif sehingga menimbulkan konflik di perusahaan tersebut.

Managemen perlu saling mengingatkan kepada karyawan agar tidak menganggap remeh suatu masalah orang lain, sebaiknya karyawan selalu menghargai pekerjaan orang lain, menjaga komunikasi, dan saling memahami sebuah permasalah. Dengan demikian akan terbentuk hubungan yang baik antar sesama karyawan dalam menyelesaikan suatu permasalahan secara keseluruhan.

\section{DAFTAR PUSTAKA}

[1] Hasibuan, Malayu. 2008. Manajemen Sumber Daya Manusia. Jakarta: Bumi Aksara.

[2] Mangkuprawira, Sjafri. 2009. Bisnis, manajemen, dan Sumber daya Manusia. Jakarta: PT. Gramedia.

[3] Mangkunegara, A.P. 2008. Manajemen Sumber Daya Manusia. Bandung: Rosdakarya. 
[4] Mathis Robert L, John H. Jackson. 2009. Manajemen Sumber Daya Manusia. Jakarta: Salemba Empat.

[5] Pace, R. Wayne \& Faules, Don F. 2013. Konflik. Bandung: PT. Remaja Rosdakarya.

[6] Riduwan. 2009. Metode dan Teknik Menyusun Proposal Penelitian. Jakarta: Alfabeta.

[7] Rivai, Veithzal dan Sagala, Ela Jauvani. 2011. Manajemen Sumber Daya Manusia Untuk Perusahaan. Jakarta: PT. Raja Garfindo Persada.

[8] Sugiyono. 2011. Metode Penelitian. Bandung: Alfabeta.

[9] Sujarweni. V. Wiratna. 2015. Statistik Untuk Bisnis dan Ekonomi. Yogyakarta: Pustaka Baru Press.

[10] -------. 2015. Metodologi Penelitian Bisnis dan Ekonomi. Yogyakarta: Pustaka Baru Press.

[11] Supranto, J. 2009. Statistik Teori dan Aplikasi. Jakarta: Penerbit Erlangga. 